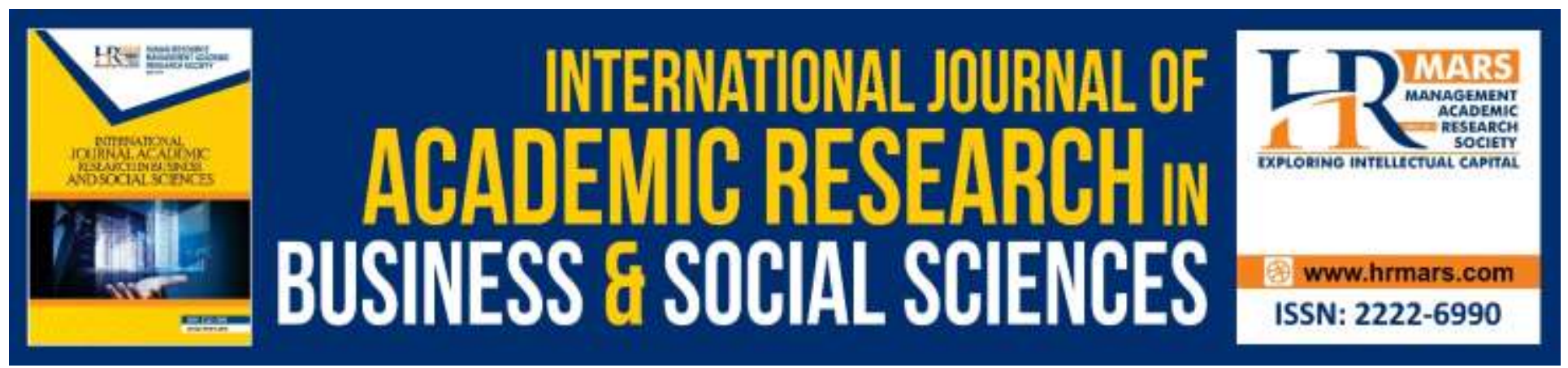

\title{
Level of Acceptance of Massive Open Online Course (MOOC) in Teaching and Learning
}

Norhasyimah Hamzah, Normah Zakaria, Nur Izeanty Hamidon, Wan Nurul Asyida Wan Roosli, Arihasnida Ariffin, Siti Nur Kamariah Rubani

To Link this Article: http://dx.doi.org/10.6007/IJARBSS/v9-i13/6864

DOI: $10.6007 /$ IJARBSS/v9-i13/6864

Received: 22 March 2019, Revised: 17 April 2019, Accepted: 02 May 2019

Published Online: 27 August 2019

In-Text Citation: (Hamzah et al., 2019)

To Cite this Article: Hamzah, N., Zakaria, N., Hamidon, N. I., Roosli, W. N. A. W., Ariffin, A., \& Rubani, S. N. K. (2019). Level of Acceptance of Massive Open Online Course (MOOC) in Teaching and Learning. International Journal of Academic in Research Business and Social Sciences, 9(13), 358-367.

Copyright: (C) 2019 The Author(s)

Published by Human Resource Management Academic Research Society (www.hrmars.com)

This article is published under the Creative Commons Attribution (CC BY 4.0) license. Anyone may reproduce, distribute, translate and create derivative works of this article (for both commercial and non-commercial purposes), subject to full attribution to the original publication and authors. The full terms of this license may be seen

at: http://creativecommons.org/licences/by/4.0/legalcode

Special Issue: Revolutionizing Education: Challenges, Innovation, Collaboration, 2019, Pg. 358 - 367

Full Terms \& Conditions of access and use can be found at http://hrmars.com/index.php/pages/detail/publication-ethics 


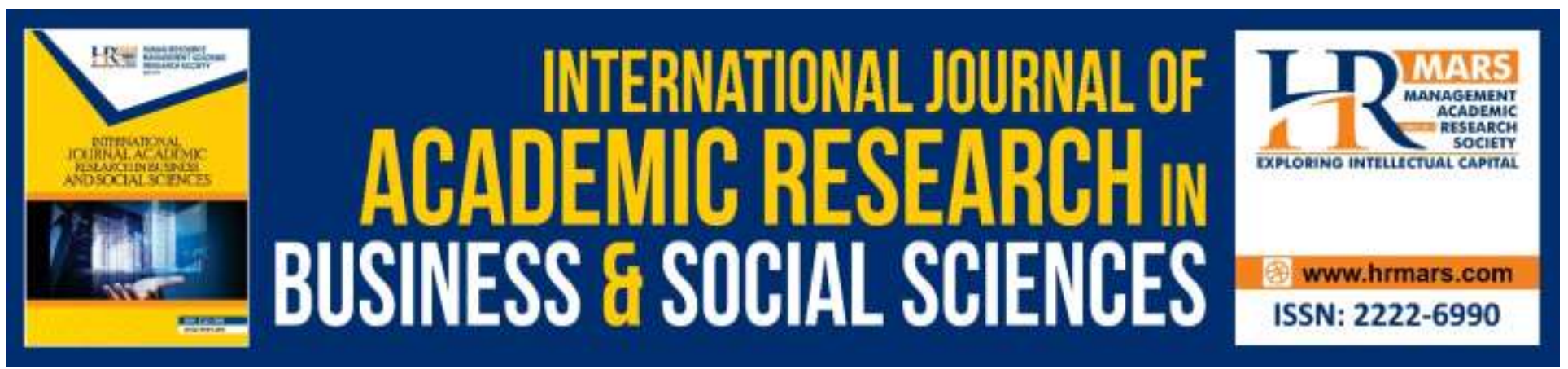

\title{
Level of Acceptance of Massive Open Online Course (MOOC) in Teaching and Learning
}

\author{
Norhasyimah Hamzah, Normah Zakaria, Nur Izeanty Hamidon, \\ Wan Nurul Asyida Wan Roosli, Arihasnida Ariffin, Siti Nur Kamariah \\ Rubani \\ Faculty of Technical and Vocational Education, Universiti Tun Hussein Onn Malaysia, 86400 Parit \\ Raja, Batu Pahat, Johor \\ Email: hasyimah@uthm.edu.my
}

\begin{abstract}
Technology-based education methods have an interest in ensuring Malaysia's position in the global rankings. Furthermore, the government intends to raise the level of online learning globally. Massive Open Online Course (MOOC) is a platform that allows the government's intention to be successfully achieved. This study aims to identify students' level of knowledge on the importance of use of $\mathrm{MOOC}$ and on the application of $\mathrm{MOOC}$ in teaching and learning. It also intends to identify the students' level of acceptance of MOOC and the level of its effectiveness in teaching and learning. A total of 247 users of MOOC from one of the public university were sampled in this study. The data were collected using a set of questionnaire and were analyzed using Statistical Package for Social Science (SPSS version 21). Results showed that the level in knowledge, usage, acceptance, and effectiveness were high among the students. From the findings, some suggestions were made to future researchers and the parties involved in university management.
\end{abstract}

Keywords: Massive Open Online Course, Technology, Teaching and Learning, Online Course

Introduction

Nowadays, the process of teaching and learning is not limited to a closed space such as a classroom. The process has changed dramatically (Hamidon, 2014) following the usage of technology in education, which allows the process to take place anywhere and anytime. This new method would encourage students to be more independent and disciplined in their learning process, hence would indirectly make learning more interesting for independent learning. This new mode of learning is referred by McDermotl (2013) as Massive Open Online Course (MOOC).

$M O O C$ is an online course that is aimed at large-scale interactive participation and open access via the web. Other than involving traditional course materials such as videos, readings, and sets of problem, the MOOCs also involves an interactive user forum, which would encourage active 
interactions between students and instructors. In MOOCs, students will learn independently and harness their new skills through the use of computer networks and smartphones.

Kim (2014) explained that MOOCs is the latest trend that offers open, massive, and accessible education to anyone who registers. Countries including the United States and Canada have been implementing MOOCs. The programmed attracted the attention of a quarter million students using MOOCs. Despite the challenges of cost control particularly in e-Learning, MOOCs have been able to generate returns because of the courses are open to the wider network of participants or students who intend to pursue study with a mode that is more flexible and independent.

According to the Malaysian Education Blueprint (Higher Education) 2015 to 2025, online learning via electronic means is a teaching model that is becoming the primary method for expanding access to education, improving the quality of teaching and learning, and enabling learning to adapt to the needs of students. Two decades into implementation, the Malaysian education system intends to progress towards the next phase of learning based on Information and Communication Technology (ICT) of Global Online Learning (GOL). Malaysia is firm in its quest to ensure that the education in the country can compete with that of the great nations. Even ninth surge in the Malaysian Education Blueprint (Higher Education) demand online learning be implemented at global level. However, the question that arises is whether the implementation of MOOC has improved online learning. The implementation of $\mathrm{MOOC}$ in all institutions of higher learning necessitates the understanding of MOOC among students and educators.

\section{Massive Open Online Course (MOOC)}

Although MOOC is still new, it is said to be commendable in terms of pedagogy and SelfMastery Driven among students. MOOC requires students to individually control their own learning, and determine when and how they can get involved in the learning sessions. Allison et al. (2015) relates that $\mathrm{MOOC}$ has attracted a wide variety of students with different levels of motivation and previous experience. Overall, the efforts for excellence in the use of MOOC courses depend on the students themselves. Problems will interactions between students and instructors. In MOOCs, students will learn independently and harness their new skills through the use of computer networks and smartphones.

Kim (2014) explained that MOOCs is the latest trend that offers open, massive, and accessible education to anyone who registers. Countries including the United States and Canada have been implementing MOOCs. The programmed attracted the attention of a quarter million students using MOOCs. Despite the challenges of cost control particularly in e-Learning, MOOCs have been able to generate returns because of the courses are open to the wider network of participants or students who intend to pursue study with a mode that is more flexible and independent. Occur if the students fail to engage in MOOC actively and do not have proper time management. In such cases the students will face failure in the course undertaking.

The teaching and learning process through the use of $\mathrm{MOOC}$ as a medium is considered informal learning. As Gutierrez et al., (2015) concluded, students preferred to study formally (faceto-face) through the traditional method's design and planning. They were dissatisfied with informal learning particularly in terms of its planning, design, and evaluation, which indicates that the biggest problem in informal learning is the assessment. 
The above mentioned issues necessitate the identification of the use of MOOC in teaching and learning. The use of $\mathrm{MOOC}$ is on the rise and the Ministry of Education (MOE) has advised all higher education institutions to use MOOC. In order to improve MOOC usage, students' level of knowledge about the importance of $\mathrm{MOOC}$ and the type of application in $\mathrm{MOOC}$ for teaching and learning process need to be revived, as well as their acceptance in MOOC usage in teaching and learning. Also required is an evaluation of the impact of $\mathrm{MOOC}$ among students. The findings can benefit the parties involved especially those in Technical and Vocational Education Training (TVET) institutions and universities in order to increase the level of MOOC usage in teaching and learning.

\section{Methodology}

This study adopted a quantitative approach in descriptive form and the data were collected using a survey form. Chua (2006) explained that descriptive survey research methods are popular due to extensive use, the similar way of control, the fast means of data collection, and the use of large sample size. Data analysis directly from survey respondents hence the generalizability of the results. The use of a survey form allowed the researcher to obtain response from many respondents hence saved the researcher's money, energy, and time in conducting the research. The study involved students in a course that used MOOC in teaching and learning, which is the Data Structures and Algorithms provided by the management party from MOOC Universiti Teknologi Malaysia (UTM).

Population refers to the sample units that will be selected (Ghauri \& Gronnhaung, 2005). The population for this study are students who have used MOOC in Data Structures and Algorithms course at Universiti Teknologi Malaysia (UTM). The total number of students registered for the course was 870. The sampel are 265 respondents based on Krejcie and Morgan (1970) table. However, for this study, 274 students were taken from the registered number of students. As mentioned by Masri (2005), a researcher should undertake inexpensive method of sampling but the samples collected must be adequate and valued. In this study, random sampling was adopted to collect information from a particular group of samples in order to meet the research objectives. A simple random sample selection process is a process in which all individuals in a particular population has an equal chance to be selected as the sample.

\section{Research Instrument}

The tables and figures should be numbered consecutively. Figures and tables haven't cited in the text should not be presented. Figures and tables should be placed close after their first reference in the text. All figures, tables, formulas, etc. must be within the margin. The tables and figures should be one line of space above and one line of space below before the text continues. The questionnaire consisted of several items based on the research objectives. Talib (2013) recommended the questionnaire method for its ability to obtain response easily from respondents, low cost, and convenience. The questionnaire was adapted from the previous study and approved by four experts. It consists of five sections. The questionnaire consist five section where are demographic of respondents (four items), level knowledge students about the importance of using MOOC (five items), usage of application in MOOC among students in teaching and learning (eight items), level of its acceptance of students toward MOOC (eight items) and effectiveness of using MOOC (ten items). This questionnaire using Likert Scale to obtain response from the respondents. It consists of five point scale (strongly agree, agree, uncertain, disagree and strongly disagree). 


\section{Validity and Reliability Instruments}

The test of validity and reliability of a research instrument is important in order to avoid the fidelity of the instrument used in a study. To ensure that the questionnaire was reliable and valid, the researcher sought confirmation from four experts in the field of e-learning pedagogy in order to ensure that the questionnaire items meet the requirements of the study. The experts were asked to assess the questionnaire in terms of content and presentation of language style prior to the pilot study. The questionnaire was adapted from those used in previous studies.

To ascertain the reliability of the questionnaire, a pilot study was conducted on 30 respondents among MOOC users. In this study, the reliability of the questionnaire, which was related to the use of MOOC in teaching and learning among students, was determined by calculating Cronbach alpha reliability coefficient. The acceptable Alpha value was set at 0.6 following Bond and Fox (2007) recommendation that 0.6 to 0.69 be the acceptable level of reliability, whereas values less than 0.60 indicate that the items are similar or overlap each other. Table 1 show tabulates these indicators.

Table 1. Cronbach Alpha value tables (Bond and Fox, 2007)

\begin{tabular}{ll}
\hline Score Alpha Cronbach & Level of Reliability \\
\hline $0.90-1.00$ & very good and consistent \\
\hline $0.80-0.89$ & good \\
\hline $0.70-0.79$ & good and acceptable \\
\hline $0.60-0.69$ & acceptable \\
\hline $0.5-0.59$ & items need to be improved \\
\hline$<0.49$ & item need to be dropped
\end{tabular}

Score of Alpha Cronbach is 0.83 . Results from the pilot study show that the items used in the questionnaire are at good levels (Table 1). Five point Likert scale that using in this study. The value reliability (alpha Cronbach) for section 2 is 0.694 , section 3 is 0.963 , section 4 is 0.927 and section 5 is 0.864 .

\section{Data Analysis}

The descriptive data analysis involved calculating the mean frequency, percentage, and standard deviation. Inferential analysis was used to describe the relationship between variables (Chua, 2006). The respondents' responses were analysed using Statistical Package for Social Science (SPSS) version 21. Analyses were performed on the respondents' demographic information, their level of knowledge about the importance of using MOOC, the applications used of respondents' and their level of acceptance for MOOC. The findings were interpreted in the form of tables, arranged according to the mean scores from the highest to the lowest in order to facilitate further analysis. Table 2 show the mean scores obtained were interpreted by referring to the interpretation by Ghafar (2003). 
Table 2. Interpretation of Mean Score (Ghafar, 2003)

\begin{tabular}{cc}
\hline Score Mean & $\begin{array}{c}\text { Level } \\
\text { Interpretation }\end{array}$ \\
\hline $0.00-1.49$ & Very Low \\
\hline $1.50-2.29$ & Low \\
\hline $2.50-3.49$ & Modest \\
\hline $3.50-4.49$ & High \\
\hline $4.50-5.00$ & Very High \\
\hline
\end{tabular}

\section{Research Findings}

Section 1 of the questionnaire queries the respondent's demographic information, which includes their gender, age, and race. Table 3 shows the analysis for this section.

Table 3. Analysis of Respondent Demographics

\begin{tabular}{ccc}
\multicolumn{2}{c}{ Respondent's Information } & Total of Respondents \\
\hline Sex & Male & 74 \\
\cline { 2 - 3 } Age & Female & 200 \\
& Under 18 years & 4 \\
\cline { 2 - 3 } & $19-25$ years & 250 \\
\hline $26-30$ years & 13 \\
\hline 31 and above & 7
\end{tabular}

The findings obtained in section 2, namely the level of knowledge on the importance of MOOC among student shows that the highest mean is 4.03 where are the respondents know that the MOOC is a requirement in teaching and learning of 21st century. Then, the lowest mean for section 2 is respondents know that they will miss out in teaching and learning if not using MOOC (mean is 3.57). Next, the findings reported in section 3 where is about analysis of the application in MOOC by the students in teaching and learning. The highest mean for section 3 is respondents can answer online quiz provided by lecturers by using MOOC (mean is 3.91). The lowest mean for section 3 is respondents using comments field provided in the MOOC to make discussion with colleagues and lecturers (mean is 3.53).

The finding for section 4 where is about analysis the level of acceptance use of MOOC among students in teaching and learning. The highest mean for section 4 is respondents found using MOOC, they can learn at any place as long as there have an internet connection (mean is 4.07). Then, the lowest mean is 3.63 which the respondents like to use MOOC in the process of teaching and learning. Section 5 is about the analysis level of the impact using MOOC. The highest mean for this section is 3.90 where the respondents found that MOOC successful make they can communicate with friends from various races and countries. The lowest mean for this section is 3.74 where the respondents found that $\mathrm{MOOC}$ successful make the ability using imagination to get creative ideas. 


\section{Discussion}

The descriptive analysis concluded that overall, the students' level of knowledge about the importance of $\mathrm{MOOC}$ in teaching and learning is at the high tendency level. $\mathrm{MOOC}$ is an alternative that can be used as a pedagogical tool for teaching in the twenty-first century. Abdul Halim (2015) proposed the use of computers and the internet in addition to other electronic equipment for teaching and learning in this era. Furthermore, MOOC has received much media attention recently, and it has been portrayed by some as a "revolution" (Friedman, 2012) and "noble" (Caplan, 2013). Therefore students of this century should have knowledge on MOOC so that they can use MOOC in teaching and learning.

This is in line with the views of Jamilah et al., (2011), who explained that the importance of knowledge as knowledge is the capacity to acquire, retain, and use information. The finding also shows the students' tendency to use applications in the MOOC was at the high level. MOOC provides several applications, the most frequently used being the applications that include online quizzes. The students also used the comments field to act as a forum for discussion, which allowed them to engage with each other and exchange knowledge and ideas, or create a sense of community (Hollands \& Tirthali, 2014; Christou \& Stamou, 2013).

The finding also indicate that students' level of acceptance towards MOOC was high, a finding that corresponded to Bove'e et al., (2007), who found that to students who use the computer in an enjoyable manner and who do not fear the computer, considered computer as important and useful in their everyday life, and they believed that the computer has a positive impact on individuals and society. The students believed that by using MOOC, they can learn anywhere as long as there is an internet connection. This means that the learning was not limited in terms of time and place. The students can also take a course from a distance and from wherever they are (Duratul, 2013). In addition, one of the aspects of MOOC preferred by the students was the fact that the course is free. Pappano (2012) named the year 2012 as the "Year of the MOOC" because teaching and learning materials were available for free and the year opened the "door" to a group of elite universities to accept more potential students. Indeed, many MOOC platforms offer a variety of courses from leading universities of the world for free (Duratul, 2013; Anuar \& Shahibi, 2018). O'Connor (2014) showed that a large number of participant in free online courses are more likely to review their teaching materials and learning that are loaded in the portal only rather than to complete the course until they obtain the certification of completion for the course.

The finding indicate that the impact of the use MOOC in teaching and learning was also high. After using the MOOC, the students found improvement in themselves. They were able to communicate with friends from various races and countries. The concept of MOOC is openness at large scale and thus it allows users to have contacts not only from Malaysia but also from all over the world. This indicates that the students have good communication and interpersonal skills after using the MOOC. The use of ICT in teaching and learning were also found to have a positive impact on the students. The online learning allowed the students to observe silently and passively, and the classroom turned active in a virtual environment. The students were also found actively contributing their ideas. Such a behavior has been observed by previous researchers including Parker et al. (2007), Ahmad et al. (2012), Atan and Badusah (2013), Harris (2012), and Loving and Ochoa (2010). Open Learning is expected to develop more responsible, independent, and self-sufficient students who can compete 
INTERNATIONAL JOURNAL OF ACADEMIC RESEARCH IN BUSINESS AND SOCIAL SCIENCES

Vol. 9, No. 13, Special Issue: Revolutionizing Education: Challenges, Innovation, Collaboration., 2019, E-ISSN: 2222-6990 @ 2019 HRMARS

in the international arena. (Azman, 2014; Tepus, 2018). In addition, Yu Ling Lin et al., (2014) stated that students who learn through MOOC can improve their problem-solving skills.

\section{Conclusion}

The finding noted a high level of the students' knowledge about the importance of MOOC in teaching and learning, the students' use of the application of the MOOC in teaching and learning, as well as their acceptance on the use of MOOC. This indicates that the use of teaching and learning in a blended learning through the MOOC platform can be received by the students. The twenty-first century education requires the use of technology in teaching and learning pedagogy. MOOC is one of the platforms that are appropriate in the era of rapidly changing technology. It carries the concept of learning across the border with no age limit setting, and cost burden can be reduced. MOOC has the potential to transform conventional or traditional learning style to a style of modern and hightech learning. From the aspect of fulfilling the needs of the learning process of all time, MOOC is able to provide content that is freely available in a variety of platforms. MOOC also gives the chance to students to explore the world outside through internet technology. Internet is rich in knowledge that needs to be mined and refined by the students.

Next, based on the results, the researchers made several proposals and recommendations for consideration by the parties concerned. The universities management may establish an organisation or a responsible body for managing the $\mathrm{MOOC}$ in order to ensure its consistent running. Such an organisation is vital for managing MOOC particularly in constructing the content in MOOC. In addition, university lecturers may propose the use of teaching and learning methods that are appropriate for students. In the twenty-first century, students are more exposed with the methods for self-learners, particularly with the use of technology. Therefore, lecturers should switch from conventional methods to new methods such as MOOC. The use of MOOC can help students in their academic achievement. As for students in the twenty-first century, they must be sensitive to changes in technology in teaching and learning in order to keep abreast with the development in technology. In this century, the use of internet and online learning is so prevalent. In fact, students in this century is said to have a computer or even a smartphone that allows them to use these tools as a means to assist in teaching and learning.

\section{Acknowledgements}

This research was supported by Short Term Grant (STG) at Universiti Tun Hussein Onn Malaysia (U647).

\section{References}

Ahmad, M., Abbas, M., Wan-Yahaya, W. A. J., \& Abdul-Salam, S. N. (2012). Investigating the Knowledge Creation Processes in a Learning Management System (LMS). Proceedings of Knowledge Management International Conference, pp. 652-656.

Anuar, N. B. C., \& Shahibi, M. S. Bin. (2018). The Effect Of Knowledge Management Capacity In Innovation Performance. International Journal of Academic Research in Progressive Education and Development, 7(3), 314-326.

Atan, S. S., \& Badusah, J. (2013). Aplikasi Rangkaian Sosial Google Plus dalam Pengajaran dan Pembelajaran Komponen Sastera. Jurnal Pendidikan Bahasa Melayu, 3(1), pp. 31-41 
INTERNATIONAL JOURNAL OF ACADEMIC RESEARCH IN BUSINESS AND SOCIAL SCIENCES

Vol. 9, No. 13, Special Issue: Revolutionizing Education: Challenges, Innovation, Collaboration., 2019, E-ISSN: 2222-6990 @ 2019 HRMARS

Azman C. (2014). Dasar E-Pembelajaran Negara (DePAN), MOOC dan peranan PTM. Buletin Sokongan Penyelidikan \& Pendidikan PTM. Bil 8 Mei 2014. Universiti Kebangsaan Malaysia.

Bond, T. G., \& Fox, C. M. (2007). Fundamental measurement in the human sciences.

Bove, E. L., de Leval, M. R., Migliavacca, F., Balossino, R., \& Dubini, G. (2007). Toward optimal hemodynamics: computer modeling of the Fontan circuit. Pediatric cardiology, 28(6), 477-481.

Caplan, S. (2013). MOOCs - massive open online courses: Jumping on the bandwidth. The Guardian. Dicapai dari http://www.theguardian.com/science/occams-orner/2013/jun/06/moocsmassive-open-online-courses

Chua Y. P. (2006). Kaedah dan Stastik Penyelidikan: Asas Penyelidikan: Buku 2. Kuala Lumpur: McGraw-Hill

Christou, S., \& Stamou, A. G. (2013). Representations of military sociolect in Greek cinema. Multilingual Academic Journal of Education and Social Sciences, 1(2), 15-24.

Hamzah, N., Zakaria, N., Hamidon, N. I., Roosli, W. N. A. W., Ariffin, A., \& Rubani, S. N. K. (2019). Level of Acceptance of Massive Open Online Course (MOOC) in Teaching and Learning. International Journal of Academic in Research Business and Social Sciences, 9(13), 360-369.

Duratul, A. Y. (2013). MOOC: Suatu Inovasi P\&P. Buletin Sokongan Penyelidikan \& Pendidikan PTM. Bil 6 Mac 2013. Universiti Kebangsaan Malaysia.

Friedman, T. L. (2012). Come the revolution. The New York Times, A25. Retrieved from http://www.nytimes.com/2012/05/16/opinion/friedman-come-the-revolution.html

Ghauri, P. N., \& Grønhaug, K. (2005). Research methods in business studies: A practical guide. Pearson Education.

Gutierrez-Santiuste, E., \& Gallego-Arrufat, M. J. (2015). Internal structure of virtual communications in communities of inquiry in higher education: Phases, evolution and participants' satisfaction. British Journal of Educational Technology, 46(6), 1295-1311.

Hamidon, Z. (2014). An Application of Cloud Computing in Teaching and Learning in a Post Graduate program at Open University Malaysia. Conference on Professional Development in Education (PDE2014), Widyatama University Indonesia, Open University Indonesia and Open University Malaysia.

Harris, C. (2012). The Uses of facebook technologies in Hospitality Curriculum on an Experiential Learning Platform for a New Generation of Students. Asia Pasific Journal of Marketing and Logistics, 24(5)

Hollands, F. M., \& Tirthali, D. (2014). MOOCs: Expectations and Reality. Full report. Online Submissionhttp://books.google.com.my/books?id=XOSyB_xZ28EC\&pg=PA55\&dq=pensampela $\mathrm{n}+$ rawak+sistematik\&hl=en\&sa=X\&ei=ceO8UKf9Ec_trQfLkYDADQ\&ved=0CDMQ6AEwAQ\#v=0 nepage $\& \mathrm{q}=$ pensampelan\%20rawak \%20sistematik\&f=false

Kim, P. (2014). Massive open online courses: the MOOC revolution. Routledge.

Loving, M., \& Ochoa, M. (2011). Facebook as a classroom management solution. New Library World, 112(3/4), 121-130.

Littlejohn, A., Hood, N., Miligan, C., \& Mustaiin, P. (2015). Learning in MOOCs: Motivations and selfregulated learning in MOOCs. Internet and Higher Education 29 (2016) 40-48.

Masri, S. (2005). Kaedah penyelidikan dan panduan penulisan: esei, proposal, tesis. Dicapai dari mybooks.com.my: 
McDermotl, I. E. (2013). Lifelong Learning: On the Web Continuing Education for Independent Students.

O'Connor, F. (2014, January 23). Edx Enrollment Data Shows Online Learners Are More Browsers Than Finishers. Dicapai dari http://www.cio.com/article/print/746978

Pappano, L. (2012). The Year of the MOOC. The New York Times, 2(12), 2012.

Parker, K. R. dan Cho, J. T. (2007). Wiki as a Teaching Tool. Interdisciplinary Journal of Knowledge and Learning Objects, vol. 3, pp. 57-72

Pelan Pembangunan Pendidikan Malaysia (Pengajian Tinggi) PPPM (PT) 2015-2025

Othman, T. (2013). Asas Penulisan Tesis Penyelidikan \& Statistik. Serdang:Penerbit Universiti Putra Malaysia.

Tepus, A.-M. (2018). The Relationship between the Capital Market and the Real Economy. The Case of the European Union, International Journal of Academic Research in Accounting, Finance and Management Sciences 8 (2): 164-169.

Lin, Y., Lin, H., Hung, T. (2015) Value hierarchy for Massive Open Online Course. Computers in Human Behavior 53 (2015) 408-418. 